УДК 658.152

DOI: https://doi.org/10.32782/2415-8801/2021-2.9

Лагун A.I.

аспірант кафедри міжнародного обліку та аудиту, Державний вищий навчальний заклад «Київський національний економічний університет імені Вадима Гетьмана»

\author{
СУТНІСТЬ ТА ЕКОНОМІЧНА ПРИРОДА \\ КРАЇНО-РЕГІОНАЛЬНИХ МОДЕЛЕЙ БЕНЧМАРКІНГУ \\ З ОГЛЯДУ ВИЗНАЧЕННЯ ЇХНІХ КОНКУРЕНТНИХ ФАКТОРІВ
}

\begin{abstract}
Статтю присвячено існуючій сьогодні типізації крайново-регіональних моделей, щцо трунтується, головним чином, на критеріях щодо масштабів і структури венчурного фінансування, ступеня розвитку національних рінансових ринків, рівня концентрації банківського капіталу та участі банків в управлінні корпоративним сектором, доступності венчурного фінансування для підприємницьких бізнес-структур, частки банківського капіталу у венчурному фінансуванні інвестиційних проєктів, частки корпоративного сектору у фінансуванні венчурних фондів, ступеня розвитку ринку злиттів і поглинань, рівня захисту прав міноритарних інвесторів та концентрації власності у реальному секторі економіки. Вагомими конкурентними перевагами ринкової моделі венчурного фінансування інновацій с наявність найкрацих у світі міжнародних бізнес-икіл; глибокі коопераційні зв'язки мізж університетами, урядовими лабораторіями і приватними компаніями. А поглиблення процесів техноглобалізму надас венчурному бізнесу потужного імпульсу розвитку.

Ключові слова: венчур, глобалізачія, бенчмаркінг, інновації, венчурне фінансування.
\end{abstract}

\title{
ESSENCE AND ECONOMIC NATURE OF COUNTRY-REGIONAL BENCHMARKING MODELS IN ORDER TO DETERMINE THEIR COMPETITIVE FACTORS
}

Lahun Antonina Kyiv National Economic University named after Vadym Hetman

The article is devoted to the current typification of country-regional models, which is based mainly on criteria for the scale and structure of venture financing, the degree of development of national financial markets, the level of concentration of bank capital and participation of banks in corporate sector management, the availability of venture capital financing. structures, share of bank capital in venture financing of investment projects, share of corporate sector in financing of venture funds, tupenya of mergers and acquisitions, the protection of minority investors and the concentration of ownership in the real economy. The criteria of classification of country-regional models of venture financing of innovative projects that cannot fully reflect its impact on the structural dynamics of national and global innovation development and should be 
supplemented by a number of additional criteria are considered. It is also the market model most widely used in the AngloSaxon countries. The presence of the best international business schools in the world is also a major competitive advantage of the market model of venture financing for innovation; deep cooperative links between universities, government laboratories and private companies. The role of the state in supporting the venture industry is analyzed, since in the market model it consists in direct investment of state funds into innovative companies (ie participation in capital) and high-tech programs and projects, as well as implementation of guarantee programs for the development of venture activity and creation of proper regulatory, organizational-economic, financial-investment and credit-tax conditions of its support. The strategic goal is most realized today in countries with a market model of venture financing, where it has long proven its high efficiency as a significant source of innovative development. And, the deepening of the processes of technoglobalism gives the venture business a powerful impetus for development, transforming it in accordance with the impact of global economic trends and stimulating the scale-up and diversification of the regional and sectoral-sectoral structure of venture capital investments.

Keywords: venture, globalization, benchmarking, innovation, venture financing.

Постановка проблеми. Венчурне підприємництво як особливий вид економічної діяльності, пов'язаний iз реалізацією ризикових інноваційних проєктів із метою одержання підприємницького і засновницького доходу, характеризується доволі широким діапазоном інституційних та організаційно-економічних відмінностей за країнами і регіонами. Виходячи із цього, високої теоретичної і практичної значущості набуває проблематика щодо системного країново-регіонального бенчмаркінгу його моделей із метою визначення найбільш конкурентних із них та ідентифікації чинників, що забезпечують високу ефективність венчурного фінансування.

Аналіз останніх досліджень і публікацій. Вагомий внесок у дослідження даної проблематики зробили багато зарубіжних та вітчизняних учених: А.М. Поручник, Я.М. Столярчук, Л.Л. Антонюк, Д.О. Ільницький [6], В.В. Зянько [2], М.Н. Кузнєцова [3], Е.С. Акельєв та ін. Але поза їхньою увагою залишаються питання класифікації моделей венчурного фінансування інноваційних проєктів, які мають бути доповнені низкою додаткових критеріїв.

Постановка завдання. Мета статті - охарактеризувати класифікації моделей венчурного фінансування інноваційних проєктів.

Виклад основного матеріалу дослідження. У даному контексті важливо зазначити, що існуюча сьогодні типізація країново-регіональних моделей грунтується, головним чином, на критеріях щодо масштабів і структури венчурного фінансування, ступеня розвитку національних фінансових ринків, рівня концентрації банківського капіталу та участі банків в управлінні корпоративним сектором, доступності венчурного фінансування для підприємницьких бізнесструктур, частки банківського капіталу у венчурному фінансуванні інвестиційних проєктів, частки корпоративного сектору у фінансуванні венчурних фондів, ступеня розвитку ринку злиттів і поглинань, рівня захисту прав міноритарних інвесторів та концентрації власності у реальному секторі економіки.

При цьому не можна випускати з уваги ще одну важливу обставину: подібні критеріальні критерії класифікації країново-регіональних моделей венчурного фінансування інноваційних проєктів не можуть повною мірою відобразити його вплив на структурну динаміку національного і глобального інноваційного розвитку, тож мають бути доповнені низкою додаткових критеріїв. Це - рівень державного регулювання венчурного підприємництва, домінуючі механізми й інструменти його державної підтримки, джерела та пріоритетні науково-технічні напрями венчурного фінансування, його вартісні обсяги залежно від стадії реалізації інноваційних проєктів, корпоративні стратегії і бізнес-моделі венчурного менеджменту. Саме така розширена система критеріїв здатна, на нашу думку, сповна відобразити існуючі міжкраїнові і міжрегіональні диференціації у ключових параметрах розвитку систем венчурного фінансування інноваційних проєктів, розкриває ключові їхні конкурентні переваги i «вузькі місця», а також відбиває альтернативні підходи до організації фінансування інновацій (лінійна чи нелінійна), охоплені інноваційними процесами галузі та інтенсивність фінансування радикальних інновацій і ранніх стадій досліджень і розробок. Таким чином, на основі зазначеної сукупності критеріїв можна виокремити ринкову, корпоративно-державну, кластерно-мережеву та мезокорпоративну моделі венчурного фінансування інноваційних проєктів, комплексну характеристику яких наведено в табл. 1.

Що стосується ринкової моделі, то вона отримала найбільшого поширення в Ізраїлі та країнах англосаксонського економічного поясу (США, Великобританії, Канаді, Ірландії, Австралії). Вона характеризується насамперед: 1) орієнтацією на нелінійні інноваційні процеси, високою доступністю венчурного капіталу для всіх учасників інноваційних процесів, а також фінансуванням системи генерування інновацій на основі розбудови розгалуженої системи зворотних зв'язків між усіма іiі компонентами та тісного «ув'язування» технічних можливостей інноваторів з інноваційними потребами ринку; 2) здатністю оперативного продукування радикальних і поліпшуючих інновацій завдяки активному застосуванню ефекту дифузії (спіловеру) інновацій та підвищенню спроможності національних економік щодо оперативного структурного «реагування» на виникнення будь-яких проблем технологічного характеру; 3) наявністю високорозвинутих, чітко структурованих, високоліквідних і диверсифікованих щодо інструментальної структури фондових ринків, що $є$ важливими інституційними майданчиками обслуговування операцій ризикового венчурного фінансування; фінансування інвесторів, індивідуальних підприємців й інших суб'єктів венчурної індустрії, а також їх виходу для отримання прибутку і генерування фінансових потоків; 4) розвинутою бізнес-культурою венчурного бізнесу та відсутністю його орієнтації на «родовід» підприємця, що дає змогу менеджерам брати на себе повну відповідальність за комерційну успішність реалізовуваних ризикових інвестиційних проєктів за рахунок передачі їм у власність певної частини акцій 
Таблиця 1

Характеристика основних моделей венчурного фінансування

\begin{tabular}{|c|c|c|c|c|}
\hline \multirow[b]{2}{*}{ Критерій } & \multicolumn{4}{|c|}{ Модель венчурного фінансування } \\
\hline & Ринкова & $\begin{array}{l}\text { Корпоративно- } \\
\text { державна }\end{array}$ & $\begin{array}{c}\text { Кластерно- } \\
\text { мережева }\end{array}$ & Мезокорпоративна \\
\hline Ступінь розвитку фінансового ринку & висока & невисока & невисока & невисока \\
\hline Рівень концентрації банківського капіталу & $\begin{array}{c}\text { не має } \\
\text { значення }\end{array}$ & висока & висока & висока \\
\hline Участь банків в управлінні компаніями & не розвинута & розвинута & не розвинута & розвинута \\
\hline Доступність венчурного капіталу & висока & низька & висока & недостатньо висока \\
\hline $\begin{array}{l}\text { Частка інституційних інвесторів у фінансуванні } \\
\text { венчурних фондів }\end{array}$ & $30-50 \%$ & менше $10 \%$ & $30-40 \%$ & менше $10 \%$ \\
\hline Частка банківського фінансування венчурних фондів & менше $20 \%$ & $40-60 \%$ & $20-30 \%$ & $30-40 \%$ \\
\hline $\begin{array}{l}\text { Частка корпоративного фінансування венчурних } \\
\text { фондів }\end{array}$ & помірна & помірна & помірна & висока \\
\hline Рівень розвитку ринку злиттів і поглинань & розвинутий & $\begin{array}{l}\text { недостатньо } \\
\text { розвинутий }\end{array}$ & $\begin{array}{l}\text { недостатньо } \\
\text { розвинутий }\end{array}$ & $\begin{array}{l}\text { недостатньо } \\
\text { розвинутий }\end{array}$ \\
\hline Рівень захисту прав міноритарних інвесторів & високий & обмежений & високий & обмежений \\
\hline Концентрація власності у реальному секторі & низька & висока & висока & висока \\
\hline
\end{tabular}

підприємницьких структур; 5) відносно ліберальними інституційними механізмами регулювання венчурної індустрії, що забезпечують підприємцям можливості легкого заснування і закриття венчурного бізнесу, формування фондів виробничого нагромадження капіталу, збереження більш високого порівняно з європейськими й азійськими компаніями проценту від прибутків тощо.

Вагомими конкурентними перевагами ринкової моделі венчурного фінансування інновацій $є$ також наявність найкращих у світі міжнародних бізнес-шкіл; глибокі коопераційні зв'язки між університетами, урядовими лабораторіями і приватними компаніями; а також ефективна система ідентифікації і захисту прав інтелектуальної власності 3 результативним моніторингом рівня виконання контрактних зобов'язань у цій сфері щодо сплати роялті і ліцензійних платежів. Не слід скидати $з$ рахунків і доволі розвинуту систему інституційних інвесторів із великомасштабним нагромадженням капітальних ресурсів, що спрямовуються на фінансування ДіР та комерціалізацію їхніх результатів.

Що ж стосується ролі держави у підтримці венчурної індустрії, то у ринковій моделі вона полягає у прямому інвестуванні державних коштів в інноваційні компанії (тобто участі у капіталі) та високотехнологічні програми і проєкти, а також реалізації гарантійних програм розвитку венчурної діяльності та створенні належних нормативно-правових, організаційно-економічних, фінансово-інвестиційних та кредитно-податкових умов іiі підтримки. На нашу думку, сукупність зазначених іманентних характеристик ринкової моделі фінансування інновацій детермінує її високу спроможність щодо докорінної трансформації існуючих принципів, форм і методів організації виробничих і технологічних процесів (реінжинірингу бізнес-процесів, діджиталізації виробничих систем, упровадження у виробництво сучасних інформаційних систем і технологій); продукування креативних технічних, організаційно-економічних, фінансово-інвестиційних та управлінських ідей; проведення масштабних досліджень i розробок за всіма напрямами науково-технічного прогресу; розбудови одиничної моделі міжнародного поділу праці і фрагментації міжнародного виробництва, а також системної інноватизації усіх підсистем економічної системи суспільства та організації масового промислового виробництва товарних інновацій.

Не випадково саме держави 3 домінуючою ринковою моделлю венчурного фінансування інноваційних проєктів уже давно перетворили національний венчурний бізнес та інвестиційні вкладення у дослідження і розробки на високодохідну сферу своїх народногосподарських комплексів. Достатньо сказати, що у цих державах середній рівень дохідності інвестицій у ДіР стабільно становить від 30: до 70\% річних, що дає широкі можливості прибуткового вкладення венчурних інвестицій за найбільш пріоритетними напрямами науковотехнічного прогресу. Так, упродовж 2014-2018 pp. щорічні вартісні обсяги венчурних капіталовкладень в економіці Сполучених Штатів Америки стабільно перевищували 70 млрд дол. США, що інвестувалися у понад 8 тис стартапів із високою динамікою зростання; а близько 49 тис американських компаній залучили за вказаний період венчурних інвестицій на загальну суму близько 445 млрд дол. США.

Упродовж 2004-2018 рр. загальна кількість створених у Сполучених Штатах Америки венчурних фондів зросла з 1356 до 4 100; кількість компаній, створених на основі венчурного капіталу, - iз 866 до 1 167; вартісний обсяг капіталу, акумульованого венчурними фондами, - 3 262,8 до 689,3 млрд дол. США; кількість існуючих венчурних фондів - 31128 до 1 884; кількість компаній, що залучали венчурний капітал в останні вісім років, - із 814 до 1 047; активи в управлінні венчурних фондів - з 158,2 до 403,5 млрд дол. США; середній розмір венчурного фонду - 112,5 до 209,4 млн дол. США; середній розмір компанії, створеної на основі венчурного капіталу, - 3 173,6 до 242,4 млн дол. США; медіанний розмір венчурного фонду - 3 43,5 до 75 млн дол. США. І лише медіанний розмір компанії, створеної на основі венчурних інвестицій, зменшився за вказаний період із 59,4 до 38,6 млн дол. США.

Достатньо сказати, що США продукують нині близько 80\% глобального обсягу інновацій, витрати на ДіР цієї держави перевищують сукупні витрати Вели- 
кобританії, Франції, Німеччини й Італії. Окрім того, тут продається 90\% нових видів товарів, що вийшли на глобальний ринок, і лише 10\% припадає на ті з них, що поступили на ринок понад п’ять років тому [1].

Запорукою високої ефективності функціонування ринкової моделі венчурного фінансування інновацій $€$ й його суб'єктна структура. Вона включає венчурні фірми (розробники високих технологій) і приватні венчурні фонди, розгалужені мережі бізнес-ангелів (приватних інвесторів, котрі мають багатий підприємницький досвід та інвестують частину власних коштів у малі венчурні фірми на ранніх етапах їх становлення [2, с. 51]), великі бізнес-структури корпоративного сектору як виробники високотехнологічної продукції i послуг. Важливо зазначити, що корпоративний венчурний капітал уже давно став стійким матеріальним ядром розбудови тісних науково-технічних зв'язків між усіма учасниками інноваційних процесів, що лежить в основі перманентної системної модернізації технологічного базису суспільного виробництва. Як приклад наведемо, зокрема, виробництво персональних комп'ютерів у США, яке завдяки механізмам венчурного фінансування впродовж 1980-1990-х років наростило свою ринкову капіталізацію практично 3 нуля до 100 млрд дол. США. Зауважимо також, що майже $70 \%$ усіх новостворених у цей період бізнес-структур даного сектору були венчурними, зокрема сучасні гіганти глобального комп'ютерного бізнесу - DEC, Apple Computers, Compaq, Sun Microsystems, Microsoft, Lotus, Intel та ін.

Ба більше, вибухоподібне зростання новітніх секторів американської економіки, насамперед IКT та біотехнологій, багато в чому було спричинене масштабним залученням у них венчурного фінансування та колосальною галузевою концентрацією венчурного капіталу. Не випадково у першій десятці найбільших глобальних компаній за показником ринкової капіталізації чотири позиції належать нині американським бізнес-структурам технологічного сектору, що були створені у тому числі за рахунок масштабних вкладень венчурних інвестицій (табл. 2). Їх загальна ринкова капіталізація станом на 1 серпня 2019 р. становила 3,4 трлн дол. США, загальні активи у 2018 р. 954,6 млрд, річний дохід - 568,6 млрд, а операційний прибуток - 157,2 млрд дол. США.

Характеризуючи ринкову модель венчурного фінансування інновацій, не можна оминути увагою i таку важливу рису американського венчурного бізнесу, як значне розширення капіталовкладень у виробництво інноваційної продукції. Підтвердженням цього є, зокрема, той факт, що у період 2007-2018 рр. середньорічний показник вкладень венчурного капіталу у проєкти фінансування посівних стадій становив близько 4,8\% загального венчурного фінансування; капіталовкладень у ранні стадії фінансування - 27,8\%, а пізніх $-67,4 \%$ [3, с. $128 ; 7 ; 8]$.

Натомість стадійна структура кількісних параметрів венчурних проєктів, реалізованих у США, показує усталене зростання в останнє десятиліття частки проєктів на посівних стадіях венчурного фінансування. Якщо у 2006 р. вона становила 13,7\% їх загальної кількості, або 458 проєктів (на ранніх стадіях - 52,4\% (1 750 проєктів), на пізніх стадіях - 33,9\% (1136 проєктів)), то у 2018 р. - 42\%, або 3760 проєктів (35\% (3 156 проєктів) та 22,7\% (2 032 проєктів)).

Подібна динаміка $є$ свідченням чітко вираженого домінування у цільових мотиваціях американських венчурних інвесторів фінансування найбільш ризикових стадій продукування інноваційно місткої продукції 3 метою присвоєння найбільшої частки глобальної технологічної ренти та нарощування конкурентних переваг на світовому ринку високотехнологічних товарів і послуг. Попри незначну частку малого інноваційного бізнесу у сукупному фінансуванні досліджень і розробок саме він характеризується високою гнучкістю та мобільністю у розбудові науково-технічного співробітництва з великими корпоративними структурами на коопераційних засадах у статусі їхніх партнерів

Таблиця 2

Топ-10 глобальних корпорацій за показником ринкової капіталізації станом на 1 серпня 2019 р.

\begin{tabular}{|c|c|c|c|c|c|c|c|}
\hline Ранг & Компанія & Країна & $\begin{array}{l}\text { Сектор } \\
\text { економіки }\end{array}$ & $\begin{array}{c}\text { Ринкова } \\
\text { капіталізація, } \\
\text { млрд дол. США } \\
\end{array}$ & $\begin{array}{l}\text { Загальні активи, } \\
\text { млрд дол. США* }\end{array}$ & $\begin{array}{c}\text { Річний дохід, } \\
\text { млрд дол. США* }\end{array}$ & $\begin{array}{c}\text { Операційний } \\
\text { прибуток, } \\
\text { млрд дол. США* }\end{array}$ \\
\hline 1 & Microsoft & США & Технології & 1058,0 & 258,8 & 110,4 & 35,1 \\
\hline 2 & Apple & США & Технології & 959,0 & 365,7 & 265,6 & 70,9 \\
\hline 3 & Amazon & США & $\begin{array}{l}\text { Комп'ютерні } \\
\text { сервіси }\end{array}$ & 959,0 & 162,6 & 232,9 & 12,4 \\
\hline 4 & Alphabet & США & Технології & 839,0 & 232,8 & 136,8 & 26,3 \\
\hline 5 & Facebook & США & Технології & 550,0 & 97,3 & 55,8 & 24,9 \\
\hline 6 & $\begin{array}{l}\text { Berkshire } \\
\text { Hathway }\end{array}$ & США & Фінанси & 496,0 & 707,8 & 247,8 & 13,9 \\
\hline 7 & Tencent & Китай & Технології & 436,0 & 109,3 & 47,2 & 14,8 \\
\hline 8 & Alibaba & Китай & $\begin{array}{l}\text { Комп'ютерні } \\
\text { сервіси }\end{array}$ & 431,0 & 114,3 & 39,9 & 11,1 \\
\hline 9 & Visa & США & Фінанси & 389,0 & 69,2 & 20,6 & 12,9 \\
\hline 10 & $\begin{array}{l}\text { JP Morgan } \\
\text { Chase }\end{array}$ & США & Фінанси & 366,0 & 853,5 & 40,1 & 11,2 \\
\hline \multicolumn{4}{|c|}{$\begin{array}{l}\text { Усього } \\
\text { le, Alphabet та Facebook }\end{array}$} & 3406,0 & 954,6 & 568,6 & 157,2 \\
\hline \multicolumn{4}{|c|}{ Усього } & 6483,0 & 2971,3 & 1197,1 & 233,5 \\
\hline
\end{tabular}

* Дані за 2018 р. 
чи субпідрядників. Окрім того, малий бізнес демонструє високу спроможність щодо реалізації ризикованих інноваційних проєктів, генерування й освоєння оригінальних наукових ідей, а також оперативність у реалізації програм і проєктів технологічної модернізації виробничих процесів навіть за умов значної обмеженості фінансових ресурсів. Достатньо сказати, що в останні сімдесят років майже $90 \%$ радикальних науково-технічних розробок у світі генерується малим інноваційним бізнесом, а у США і західноєвропейських державах малі інноваційні фірми є ліцензіатами майже $50 \%$ усіх нововведень.

Зазначені конкурентні переваги ринкової моделі венчурного фінансування інновацій детермінують тісний взаємозв'язок між наукою, виробничим сектором і державою у форматі так званої «потрійної спіралі». Дана концепція, як відомо, логічно продовжила запропоновану у 1975 р. Дж. Сабато модель трикутника інновацій та пріоритезує тристоронні рівноправні відносини між університетами, урядом та промисловістю у суспільстві знань. Саме вони лежать в основі розбудови у глобальних координатах диверсифікованих інституційних і соціальних мереж генерування, трансферу й імплементації у суспільно-господарській практиці нових знань, а отже, є головним драйвером як природної інноваційної динаміки, так і креативного оновлення усіх компонентів національних інноваційних систем [6, с. 35].

Однак, незважаючи на зазначені переваги ринкової моделі венчурного фінансування, вона не позбавлена такого недоліку, як недостатня фінансова стійкість та значні загрози виникнення «бульбашок» на національних фондових ринках. Йдеться, насамперед, про циклічний характер венчурного інвестування, значну залежність його структурної динаміки від темпів зростання валового внутрішнього продукту, а також високу схильність до переоцінювання вартості стартапів. Як приклад наведемо обвальне падіння американської фондової біржі NASDAQ у березні 2000 р., що була спричинена різким спадом у сфері технологій та колосальними втратами венчурних фондів від переоцінених низькодоходних чи збиткових стартапів. I лише з 2003 р. пожвавлення діяльності Інтернет-компаній та венчурних інвесторів знову виводить американський фондовий ринок на висхідну траєкторію зростання завдяки купівлі корпорацією еВау IP-телефонної мережі Skype, придбання компанією News Corporation вебсайту MySpace, а також успішному виходу компанії Google на IPO.

Висновки 3 проведеного дослідження. Резюмуючи, маємо наголосити, що діючі сьогодні моделі венчурного фінансування інновацій відбивають ключові іманентні особливості й специфічні характеристики національних і регіональних інноваційних систем. Вони сформувалися у результаті складної взаємодії науково-технічних, технологічних, соціально-економічних, політико-правових та інституційно-регуляторних чинників інноваційного розвитку певних країн i регіонів. Водночас найбільш визначальний вплив на їх становлення і подальший еволюційний розвиток справили науково-технологічні детермінанти, котрі у сукупності формують глобальну конфігурацію архітектоніки венчурного фінансування та забезпечують ефективну консолідацію у реальному секторі економіки грошових капіталів одних бізнес-структур та інтелектуальних ресурсів інших. Країново-регіональні моделі венчурного фінансування, що остаточно сформувалися в останні сімдесят років, забезпечують масштабне розроблення, впровадження і використання новітніх технічних, технологічних й інформаційних засобів у виробничій і невиробничій сферах та зорієнтовані на максимальну концентрацію матеріально-технічних i фінансових ресурсів на найбільш пріоритетних напрямах досліджень і розробок. Зазначена стратегічна мета найбільшою мірою реалізована сьогодні у країнах із ринковою моделлю венчурного фінансування, де воно вже давно підтвердило свою високу ефективність як вагоме джерело інноваційного розвитку. Разом із тим поглиблення процесів техноглобалізму надає венчурному бізнесу потужного імпульсу розвитку, трансформуючи його згідно $з$ дією глобальних економічних трендів та стимулюючи нарощування масштабів i диверсифікацію регіональної і галузево-секторальної структури венчурних капіталовкладень.

\section{Список використаних джерел:}

1. Жихор Е.Б., Куценко Т.Н. Финансовое обеспечение инновационного развития: опыт формирования и возможности использования. URL: http://www.ieay.ru/nauka-v-ieau/nauchnye-trudy-ieau/innovacionnoe-razvitieekonomiki-rossii-novyj-etap/finansovoe-obespechenie-innovacionnogo-razvitiya-opyt-formirovaniya-i-vozmozhnostiispolzovaniya/ (дата звернення: 20.02.2020).

2. Зиньков Д.В., Горлатов А.С. Венчурное финансирование инноваций: мировой опыт и российские реалии. Финансы и кредит. 2011. № 4(436). С. 50-57.

3. Кузнецова М.Н. Модели венчурного финансирования в развитых странах: методологический аспект. Вестник УрФУ. Серия «Экономика и управление». 2013. № 2. С. 123-133.

4. Value of venture capital investment deals in the United States 2018, by stage (in billion U.S. dollars). Statista. The Statictics Portal. URL: https://www.statista.com/statistics/423016/venture-capital-investments-usa-by-stage/ (дата звернення: 20.02.2020).

5. Value of venture capital investment in the United States from 2010 to 2015, by stage (in billion U.S. dollars). Statista. The Statictics Portal. URL: https:/www.statista.com/statistics/424846/venture-capital-investments-usa-bystage/ (дата звернення: 20.02.2020).

6. Ільницький Д.О. Глобальна конкуренція в науково-освітньому просторі : монографія. Київ : КНЕУ, 2016.

\section{References:}

1. Zhyxor E., Kucenko T. Fynansovoe obespechenye ynnovacyonnogo razvytyya: oput formyrovanyyay vozmozhnosty yspolzovanyya [Financial support of innovative development: the experience of formation and the possibility of using]. Available at: http://www.ieay.ru/nauka-v-ieau/nauchnye-trudy-ieau/innovacionnoe-razvitie-ekonomiki-rossii-novyj-etap/ 
finansovoe-obespechenie-innovacionnogo-razvitiya-opyt-formirovaniya-i-vozmozhnosti-ispolzovaniya/ (accessed 20 February 2020).

2. Zynkov D., Gorlatov A. (2011) Venchurnoe fynansyrovanye ynnovacyj: myrovoj opyt y rossyjskye realyy[Venture financing of innovations: world experience and Russian realities]. Finance and credit, no. 4 (436), pp. 50-57.

3. Kuzneczova M.N. (2013) Modely venchurnogo fynansyrovanyya v razvytyh stranax: metodology cheskyj aspect [Models of venture financing in developed countries: methodological aspect]. UrFU Bulletin. Economics and Management Series, no. 2, pp. 123-133.

4. Value of venture capital investment deals in the United States 2018, by stage (in billion U.S. dollars). Statista. The Statictics Portal. URL: https://www.statista.com/statistics/423016/venture-capital-investments-usa-by-stage/ (accessed 20 February 2020)

5. Value of venture capital investment in the United States from 2010 to 2015, by stage (in billion U.S. dollars). Statista. The Statictics Portal. URL: https:/www.statista.com/statistics/424846/venture-capital-investments-usa-bystage/ (accessed 20 February 2020)

6. Ilnyczkyj D. (2016) Global'na konkurenciya v naukovo-osvitn`omu prostori [Global competition in the scientific and educational space]. Kyiv: KNEU (in Ukrainian)

E-mail: andavydenko@kneu.edu.ua 